\title{
O distanciamento do modelo pastoral do Vaticano II e da tradição libertadora
}

The distance from the Vatican II pastoral model and the

liberating tradition

AGENOR BRIGHENTI (DDa

\section{Resumo}

Dados de quatro questões do instrumento aplicado na pesquisa de campo em busca do perfil dos "padres novos" no Brasil estão em análise: ações do modelo de pastoral dos "padres das décadas de 1970/80" que já não respondem às necessidades de hoje; ações deste modelo que continuam válidas; as maiores lacunas ou vazios na ação pastoral na atualidade; e como a ação da Igreja tem contribuído para uma sociedade mais justa e fraterna. Em um primeiro momento, faz-se uma apresentação sucinta dos dados levantados junto a padres, leigos/as, jovens, seminaristas e religiosas de duas perspectivas teológico-pastorais. Em seguida faz-se uma análise preliminar dos resultados, constatando o distanciamento da Igreja no Brasil do modelo pastoral do Vaticano II e da tradição libertadora da Igreja na América Latina. A razão aludida é o impacto sobre a pastoral da crise do projeto civilizacional moderno e a reação de medo e busca de segurança por parte segmentos da Igreja, que leva a fazer do passado um refúgio e a resgatar modelos de pastoral que a renovação conciliar havia superado.

Palavras-chave: Pastoral. Presbíteros. Vaticano II. Tradição libertadora. Crise da modernidade.

\footnotetext{
a Pontifícia Universidade Católica do Paraná (PUCPR), Curitiba, PR, Brasil. Doutor em Teologia, e-mail: agenor.brighenti@pucpr.br
} 


\section{Abstract}

Data from four questions of the instrument applied in the field research in search of the profile of the "new priests" in Brazil are under analysis: actions of the pastoral model of the "priests of the 1970's and 80's" which no longer respond to the needs of today; actions of this model which are still valid; the biggest gaps or voids in the pastoral action today; and how the action of the Church has contributed to a more just and fraternal society. In a first moment, a brief presentation of the data gathered from priests, lay people, young people, seminarians, and religious from two theologicalpastoral perspectives is made. Next, a preliminary analysis of the results is made, confirming the distancing of the Church in Brazil from the pastoral model of Vatican II and from the liberating tradition of the Church in Latin America. The reason alluded to is the impact on pastoral care of the crisis of the modern civilizational project and the reaction of fear and search for security on the part of segments of the Church, which leads to make the past a refuge and to rescue pastoral models that the conciliar renewal had overcome.

Keywords: Pastoral. Presbyters. Vatican II. Liberating tradition. Crisis of modernity.

\section{Introdução}

O segundo bloco de 10 perguntas do questionário aplicado na pesquisa de campo em busca do perfil dos "padres novos" no Brasil tinha por finalidade identificar seu perfil, em relação à visão sobre a Igreja hoje. $O$ artigo anterior apresentou os dados e uma análise relativa às três primeiras perguntas. Vamos fazer o mesmo agora com as quatro perguntas seguintes deste bloco: a) que ações do modelo de pastoral dos "padres das décadas de 1970/80" já não respondem mais às necessidades de hoje; b) que ações do modelo de pastoral dos "padres das décadas de 1970/80" continuam válidas; c) quais as maiores lacunas ou vazios na ação pastoral na atualidade; d) como a ação da Igreja tem contribuído para uma sociedade mais justa e fraterna.

Além de dados do que pensam os "padres novos", apresentaremos dados oriundos igualmente da escuta de leigos/as, jovens, seminaristas, religiosas e "padres das décadas de 1970/80". Lembrando de que se trata de dados fornecidos por agentes eclesiais de duas perspectivas teológicopastorais: padres, leigos/as, jovens, seminaristas e religiosas da perspectiva "institucional/carismática", à qual se alinham os "padres novos", e as 
mesmas categorias de agentes eclesiais da perspectiva “evangelização/libertação”, à qual se alinham os "padres das décadas de 1970/80". Lembrando que esta segunda perspectiva está em sintonia com a renovação do Vaticano II e sua recepção criativa feita pela Igreja na América Latina em torno à Conferência de Medellín, enquanto que a primeira perspectiva se distancia desta, pois se insere no processo de involução eclesial, que se estendeu principalmente durante as três décadas que antecederam o atual pontificado.

As quatro perguntas aqui em foco se remetem a três temas fundamentais: a) a vigência ou a caducidade de ações do modelo pastoral dos “padres das décadas de 1970/80", alinhado à renovação do Vaticano II e sua “recepção criativa” feita pela Igreja na América Latina em torno a Medellín, b) os vazios ou lacunas na ação pastoral hoje; c) a contribuição da Igreja para uma sociedade mais justa e fraterna. Como método de trabalho, vamos primeiramente apresentar de maneira sucinta os dados relativos às quatro perguntas em questão, para em seguida fazer uma análise de caráter mais global e de fundo dos mesmos.

\section{Breve relatório dos dados da pesquisa de campo}

Vamos então aos dados, privilegiando as respostas indicadas em primeira opção dentre as três alternativas que se pedia assinalar em ordem de importância. Também dando ênfase às respostas dos "padres novos", objeto da pesquisa realizada.

\section{Ações do modelo de pastoral das décadas de 1970/80 que já não respondem}

O modelo de pastoral das décadas de 1970/80 diz respeito à recepção da renovação do Vaticano II e da tradição libertadora da Igreja na América Latina. É a pastoral que os padres deste período impulsionaram, a mantiveram durante os tempos de involução eclesial, mas que hoje dá sinal de cansaço e mesmo de retrocesso. Por um lado, as CEBs já não são mais unanimidade e nem prioridade em relação aos movimentos e, por outro, se 
diz que já não se justificam preconceitos em relação à Renovação Carismática, o movimento de maior proeminência na esteira da pentecostalização das Igrejas cristãs, incluído importante segmento da Igreja Católica.

Concretamente, dentre as ações do modelo de pastoral dos "padres das décadas de 1970/80" que já não respondem — privilegiar as CEBs em relação aos movimentos é a alternativa indicada em primeiro lugar pelos "padres novos" (25,4\%) e os seminaristas (25,4\%) da perspectiva "institucional/carismática", assim como pelos leigos/as (26,0\%) da perspectiva "evangelização/libertação". Somam-se a esta alternativa, indicando em segundo lugar também os padres $(20,2 \%)$ e os seminaristas $(18,8 \%)$ desta perspectiva. Converge com esta alternativa a indicação dos leigos/as da perspectiva "institucional/carismática" que formar comunidade e fazer funcionar a comunidade tornou-se impossível (15,1\%), alternativa esta reforçada pelos "padres novos" nomeando-a em quarto lugar (9,0\%). Os próprios padres das décadas de 1970/80 não estão longe disso. Eles apontam em primeira opção como ação que já não responde - celebrações litúrgicas que acentuam o compromisso social (22,3\%), seguidos das religiosas da mesma perspectiva, que nomeiam esta alternativa em segundo lugar (12,5\%). É um quadro sumamente desfavorável para as CEBs, para uma Igreja comunidade de pequenas comunidades, e muito favorável para os movimentos, um modelo de Igreja alinhado ao regime de neocristandade, que o Vaticano II superou.

Em convergência com a valorização dos movimentos em relação às CEBs, outra ação do "modelo pastoral das décadas de 1970/80" que já não responde mais na Igreja hoje, indicada em primeiro lugar e com a maior convergência dos agentes eclesiais consultados, é o preconceito em relação à renovação carismática. Esta alternativa é indicada pelos jovens (31,3\%) e religiosas $(25,0 \%)$ da perspectiva "institucional/carismática", assim como pelos jovens (26,6\%), seminaristas (20,8\%) e religiosas (19,4\%) da perspectiva "evangelização/libertação". Esta mesma alternativa é reforçada pela indicação em segundo lugar pelos "padres novos" (23,9\%) e os seminaristas $(20,3 \%)$ da perspectiva "institucional/carismática", como também pelos leigos/as (12,4\%) da perspectiva "evangelização/libertação". Ou seja, as CEBs 
não só estão em situação desfavorável em relação aos movimentos como, dentre os movimentos, é a renovação carismática que goza de maior simpatia e acolhida, um movimento que em outros tempos era motivo de tensões e divisões. Em outras palavras, sobretudo para os "padres novos", fazer comunidade tornou-se impossível, o que justificaria não mais se priorizar as CEBs. Funcionam os movimentos e, dentre eles, a renovação carismática já não encontra obstáculos e, portanto, segundo os dados, não tem sentido nas celebrações litúrgicas acentuar o compromisso social.

\section{Ações do modelo de pastoral dos padres das décadas de 1970/80 que continuam válidas}

Com relação às ações do "modelo pastoral das décadas de 1970/80" que continuam válidas na Igreja hoje, os dados vão de encontro ao posicionamento dos agentes eclesiais expressado na questão anterior. Com exceção dos jovens da perspectiva "institucional/carismática" e das religiosas da perspectiva "evangelização/libertação", todas as demais categorias de agentes das duas perspectivas teológico-pastorais convergem em apontar em primeiro lugar - formação bíblica, celebração e compromisso em grupo de reflexão ou família. Indicam esta alternativa os "padres novos" $(28,4 \%)$, leigos/as (21,6\%), seminaristas $(32,1 \%)$ e religiosas $(27,3 \%)$ da perspectiva "institucional/carismática", assim como os padres (28,9\%), leigos/as (24,7\%), jovens (28,6\%) e seminaristas (33,3\%) da perspectiva "evangelização/libertação".

A princípio se poderia pensar que a indicação desta alternativa contrariaria o distanciamento das CEBs, expressado na questão anterior. Entretanto, tudo indica que grupos de reflexão ou de família são concebidos mais como movimento do que mediação para chegar às CEBs, que concebem a Igreja como eclesiogênese. Os grupos de reflexão ou de família normalmente estão no seio da paróquia tradicional, sem questionar seu modelo ou sem buscar configurar uma Igreja comunidade de comunidades. Contenta-se de que sejam e continuem grupos. Em outras palavras, tende-se a confundir "pequena comunidade" com "grupo". Comunidade eclesial se alicerça e realiza o tríplice múnus - profético, sacerdotal e régio - e grupo 
se aglutina em torno a uma realidade específica e deveria ser parte integrante de uma comunidade. Somente as religiosas da perspectiva "evangelização/libertação" nomeiam e, ainda em segundo lugar, a validade de dar mais importância às pequenas comunidades que aos movimentos (18,3\%), o que também é indicado, em terceiro lugar, pelos padres da perspectiva "evangelização/libertação" (11,3\%). Na realidade, as CEBs são expressão de outra eclesiologia que a da paróquia da cristandade, instância esta propulsora de uma pastoral de conservação, centralizada no padre, sacramentalizadora, de massa, sem vínculos comunitários e pertença eclesial, que o Vaticano II superou. Por sua vez, os movimentos apostólicos ou eclesiais, normalmente, são expressão do projeto de Igreja de neocristandade, em postura apologética frente ao mundo moderno, extensão do braço do clero em uma missão centrípeta: sair para fora da Igreja, para reconduzir para dentro dela os católicos emancipados da tutela social da Igreja.

\section{Vazios ou lacunas na ação pastoral, hoje}

Com relação aos maiores vazios ou lacunas na ação pastoral, hoje, dentre os consultados, indicam em primeira opção - a baixa do profetismo $e$ o esfriamento da opção dos pobres - "padres novos" (45,5\%), leigos/as $(22,8 \%)$ e religiosas $(30,3 \%)$ da perspectiva "institucional/carismática" e padres (40,2\%), leigos/as (19,6\%), seminaristas $(29,8 \%)$ e religiosas $(29,2 \%)$ da perspectiva "evangelização/libertação". Veja-se que os índices da porcentagem dos agentes eclesiais da perspectiva "evangelização/libertação" são muito mais altos que os índices dos agentes da perspectiva "institucional/carismática", o que corrobora a diferente sensibilidade das duas perspectivas a respeito. $O$ índice menor é dos leigos/as e, curiosamente, das duas perspectivas. Os dados confirmam o silêncio da Igreja e dos cristãos diante de situações que tempos atrás mereciam posicionamento claro, assim como o encolhimento da pastoral, ou seja, a atuação da Igreja na defesa e promoção da vida dos mais pobres. Hoje, este trabalho adquiriu um caráter mais assistencial, na ilusão de uma opção pelos pobres sem dor, sem cruz, sem tomar posição frente às causas da exclusão. 
Outra alternativa nomeada em primeiro lugar com maior incidência com relação aos maiores vazios na ação pastoral hoje é a falta de acolhimento pessoal e o desconhecimento da situação da pessoa - apontada em primeiro lugar pelos jovens (28,3\%) e seminaristas (30,4\%) da perspectiva “institucional/carismática”, em segundo lugar pelos padres (16,7\%) desta perspectiva em primeiro lugar pelos leigos (19,6\%) da perspectiva “evangelização/libertação”. Converge e reforça esta alternativa a indicação em segundo lugar de liturgias frias, sem convencimento, sem valorização da afetividade - por parte dos jovens $(16,3 \%)$, seminaristas $(11,4 \%)$ e religiosas $(18,2 \%)$ da perspectiva "institucional/carismática". Note-se que a maioria das categorias de agentes que indicam estas alternativas é da perspectiva “institucional/carismática”. E de fato se constata na prática que são características principalmente dos segmentos ligados à renovação carismática, à qual está alinhada grande parte dos “padres novos”. Nestes espaços, dá-se muita importância à dimensão terapêutica da religião e como normalmente são frequentados por pessoas machucadas, a acolhida pessoal e o conhecimento da situação concreta da pessoa não deixa de ser uma necessidade.

Em segundo lugar, a maioria das categorias de agentes consultados nomeia como lacuna na ação pastoral hoje - a centralização na paróquia e padre, burocracia e clericalismo. Alternativa apontada também pelos leigos/as (22,0\%) da perspectiva "institucional/carismática" e pelos padres (27,8\%), leigos/as (18,8\%), seminaristas $(23,4 \%)$ e religiosas $(23,6 \%)$ da perspectiva “evangelização/libertação”. Nota-se que a maioria das indicações vem dos agentes eclesiais da perspectiva “evangelização/libertação”. É coerente com o que se constata na prática, uma realidade à qual, de fato, os "padres novos" estão mais atrelados, para não dizer confortáveis e até sendo os promotores. Assumir uma paróquia é normalmente uma solene cerimônia de "posse", o que muitos bispos sacramentam em seus decretos, na contramão da sinodalidade eclesial e da corresponsabilidade de todo o Povo de Deus por todos e por tudo na Igreja. 


\section{Como a ação da Igreja tem contribuído para uma sociedade mais justa e fraterna}

Com relação a como a ação da Igreja tem contribuído para uma sociedade mais justa e fraterna, a indicações se dividem entre três alternativas principais. É indicado em primeiro lugar —o apoio a projetos de lei, como a lei Anticorrupção e da Ficha Limpa - pelos "padres novos" (21,5\%) e pelos "padres das décadas de 1970/80" (29,9\%). Somam-se a esta alternativa, nomeando-a em segundo em lugar, os leigos/as (21,2\%) da perspectiva "institucional/carismática" e os leigos/as (14,1\%) da perspectiva “evangelização/libertação”. Como se pode constatar, aqui convergem padres e leigos/as, valorizando a atuação da Igreja no espaço público, mais concretamente na esfera política do bem comum.

Outra alternativa indicada com maior convergência é educando para justiça, a partilha e o serviço aos pobres - nomeada por leigos/as (31,4\%) e religiosas (27,3\%) da perspectiva “institucional/carismática” e pelos leigos $(24,3 \%)$ da perspectiva “evangelização/libertação". Esta alternativa é reforçada pela nomeação em segundo lugar pelos padres (23,5\%) e seminaristas (19,0\%) da perspectiva “institucional/carismática" e pelos padres (24,7\%), jovens $(24,1 \%)$ e religiosas $(22,5 \%)$ da perspectiva “evangelização/libertação”. A alternativa anterior é mais pontual, esta é mais do cotidiano e processual do trabalho da Igreja, o que não deixa de ser um olhar para além de respostas imediatas e, portanto, mais importante.

Uma terceira alternativa, nomeada em primeiro lugar - levantando a voz profética diante de situações de injustiça e desrespeito de direitos - é indicada pelos seminaristas (21,5\%) da perspectiva “institucional/carismática” e pelos seminaristas $(33,3 \%)$ e religiosas $(28,2 \%)$ da perspectiva “evangelização/libertação”. Somam-se a esta alternativa, nomeando-a em segundo lugar, os jovens (11,7\%) e as religiosas (24,2\%) da perspectiva “institucional/carismática”. Já se assinalou anteriormente a baixa do profetismo, que passa também pela palavra, sempre também importante, ainda que deva estar sempre precedida pelo testemunho de uma prática consequente. 
Uma quarta alternativa nomeada em primeiro lugar, são as Campanhas da Fraternidade e a consequente criação de projetos específicos Cáritas, Ações Sociais e assistência regular aos pobres, indicada pelos jovens (38,6\%) da perspectiva “institucional/carismática” e pelos jovens (33,0\%) da perspectiva “evangelização/libertação”. Chama a atenção que somente os jovens nomeiem esta alternativa e inclusive em primeiro lugar. Os "padres novos" não demonstram muito apreço a elas (4,4\%), enquanto que padres da perspectiva "evangelização/libertação" as nomeiam em terceiro lugar (16,5\%).

Diversos aspectos chamam à atenção. O reconhecimento de uma contribuição da Igreja à sociedade de caráter mais diretamente na esfera política se restringe a padres e leigos, consequentemente, uma ação não visualizada por jovens, seminaristas e religiosas. Seminaristas e religiosas se referem mais ao profetismo diante de situações de injustiça e, os jovens, às campanhas e assistência aos pobres. Como já assinalamos, a alternativa mais nomeada em primeiro e segundo lugar é educar para a justiça e a partilha com os pobres. Aqui convergem padres, leigos/as, religiosas de ambas as perspectivas, assim como os seminaristas da perspectiva "institucional/carismática" e os jovens da perspectiva “evangelização/libertação".

\section{O que os dados nos dizem e como aparecem os "padres novos"}

Para uma análise preliminar dos dados aqui apresentados, pelo menos três aspectos precisam ser considerados: quais os pilares do modelo pastoral do Vaticano II e da tradição libertadora da Igreja na América Latina, do qual a Igreja no Brasil se distanciou, em especial os "padres novos"; quais as possíveis razões do processo de involução eclesial, vivido nas três décadas dos dois pontificados que antecederam o atual e, ainda em curso, apesar do resgate do Concílio e da tradição libertadora pelo Papa Francisco; o que configura a perspectiva teológico-pastoral "institucional/carismática", que continua se distanciando da renovação conciliar e a perspectiva “evangelização/libertação”, que resiste e, mesmo cedendo em vários 
aspectos, continua acreditando e apostando no Vaticano e na tradição eclesial libertadora.

\section{Pilares de um modelo pastoral que perdeu terreno}

O modelo de pastoral dos "padres das décadas de 1970/80" se remete à renovação do Concílio Vaticano II e sua "recepção criativa" levada a cabo pela Igreja na América Latina, em torno à Conferência de Medellín (SOBRINO, 1985, p. 105-134). Renovação conciliar e tradição eclesial libertadora são suas marcas. O Concílio Vaticano II, um divisor-de-águas na Igreja católica, é uma questão chave para entender a trajetória da Igreja desde então e a situação atual. Após mais de meio século sob seu influxo, apesar de determinados segmentos eclesiais terem tentado minimizar sua importância e transcendência, o Vaticano II tem sido um verdadeiro kairós e um "advento para o terceiro milênio" no dizer do Papa João Paulo II.

Influência especial e impacto profundo teve o Concílio na América Latina (GUTIÉRREZ, 1985, p. 213-237). Os bispos do subcontinente, se por um lado enquanto "padres conciliares" não foram propriamente "pais" do Vaticano II, contribuindo pouco nos debates e com suas conclusões, por outro lado, saíram dele como seus melhores "filhos", pois foram os primeiros a implementá-lo no continente e em suas Igrejas Locais. A Conferência de Medellín, realizada na primeira hora de seu processo de recepção, fez do Concílio um "ponto de partida”, encarnando-o de maneira peculiar em um contexto marcado pela injustiça e a exclusão.

\section{De uma Igreja "reflexo" a uma Igreja fonte}

Num texto de dezesseis documentos, as Conclusões de Medellín recolhem os dezesseis documentos do Vaticano II em uma perspectiva libertadora, à luz da opção preferencial pelos pobres. Medellín dá à Igreja na América Latina uma palavra e um rosto próprio, deixando de ser uma Igreja "reflexo" de um cristianismo romanizado, para ser uma Igreja "fonte" (LIMA VAZ, 1968, p. 17-22). Em outras palavras, na fidelidade às intuições básicas e aos eixos fundamentais do Concílio, com Medellín, na América Latina não 
houve propriamente implantação, mas "encarnação" e "desdobramento" de suas proposições. Diríamos hoje, no processo de acolhida do Vaticano II em terras latino-americanas, houve "inculturação", pois se fez do Vaticano II não apenas um "ponto de chegada", mas base para uma evangelização contextualizada, na perspectiva dos pobres e a partir da periferia. Este modo de acolhida do Vaticano II por parte da Igreja na América Latina, em Medellín, Jon Sobrino batizou de "recepção criativa".

O tempo se encarregaria de mostrar de que se tratava de uma perspectiva arrojada, que levaria a resultados que transcenderiam as fronteiras do continente. O caminho teve seus percalços. Depois de Medellín veio o freio da Conferência de Puebla (1979) à tradição libertadora latinoamericana, seguida da Conferência de Santo Domingo (1992), que significou praticamente seu estancamento (HOUTART, 1975, p. 10-24). Seria preciso esperar a Conferência de Aparecida (2007), para que o Vaticano II, na perspectiva de Medellín, fosse resgatado e re-impulsionado e, com ele, a tradição libertadora da Igreja na América Latina e Caribe.

Sobretudo, no período entre Puebla e Santo Domingo, por causa de uma fé inquieta, não foram poucas as vozes silenciadas e os profetas colocados sob suspeita. Em muitos casos, a fidelidade à causa dos mais pobres redundou em sangue derramado, como testemunha a constelação de mártires das causas sociais, que tem em Dom Romero o primeiro deles canonizado (DUSSEL, 1981, p. 70-78). De maneira inesperada, com Aparecida, houve o "renascer de uma esperança", na medida em que se fez o resgate de um modo de ser Igreja, que em meio a um tempo de involução eclesial e entrincheiramento identitário, espera contra toda esperança. Ainda mais inusitada foi a eleição do Papa Francisco, que estancaria oficialmente o processo de involução eclesial, sem que seus atores, no entanto, não só continuem se distanciando do Vaticano II e da tradição eclesial libertadora, como têm radicalizado sua posição. Mas, a oposição ao resgate da renovação conciliar não tem impedido o Papa avançar neste processo. Uma postura diferente dos "padres das décadas de 1970/80", como mostram os dados da pesquisa, que não têm conseguido ser mais resilientes e consequentes com o caminho percorrido, cedendo terreno a práticas respaldadas, como diz Aparecida, em eclesiologias e espiritualidades pré-conciliares. Os "padres 
novos", já formados em outra perspectiva, em grande medida trilham outros caminhos, até que porque nem sempre se lhes dá a conhecer o legado do Vaticano II e da trajetória da Igreja na América Latina. Os "padres das décadas de 1970/80", entretanto, mesmo com os novos ares do novo pontificado parecem não acreditar que o futuro da Igreja depende ainda em muito do que o Espírito soprou no Concílio e em sua recepção na caminhada da Igreja da América Latina. Já o Papa Francisco está convencido e luta por isso.

\section{A preciosa herança da tradição libertadora da Igreja na América Latina}

O modelo pastoral dos "padres das décadas de 1970/80", como dissemos, tem dois referenciais: a renovação conciliar e sua "recepção criativa" em torno à Conferência de Medellín. A tradição eclesial libertadora é consequência e desdobramento das intuições básicas e eixos fundamentais do Concílio Vaticano II, em um contexto marcado pela injustiça e a exclusão. Dela é originário um modelo de pastoral, que tem pelo menos cinco pilares.

Um dos principais pilares da tradição libertadora são as CEBs (Cf. AZEVEDO, 1986). O Concílio, superando o binômio clero-leigos, concebeu a Igreja como a comunidade dos batizados, na comunhão da radical igualdade em dignidade de todos os ministérios. Para a Lumen Gentium, não há dois gêneros de cristãos, mas um só - os batizados — em uma comunidade toda ela ministerial ( $L G$ 10). Tirando consequências desta nova auto-compreeensão da Igreja, para Medellín, a comunhão eclesial precisa ser real e palpável, através de verdadeiras comunidades eclesiais, no seio da qual todos são sujeitos. Isso só é possível em pequenas comunidades, como nas comunidades eclesiais de base (Med 7,4), concebidas como "célula inicial da estruturação eclesial, foco de evangelização" (Med 15,10). Trata-se de comunidades de tamanho humano, ambientais, inseridas na sociedade em uma perspectiva profética e transformadora. Aparecida, resgatando Medellín, reafirma as CEBs, assumindo a duas categorias de Medellín - célula inicial da estruturação eclesial e foco de evangelização (DAp 178). Reconhece que elas demonstram seu compromisso evangelizador entre os mais simples e 
afastados, expressão visível da opção preferencial pelos pobres (DAp 179). Por isso, para uma Igreja comunidade de comunidades, urge a setorização da paróquia em unidades territoriais menores (OLIVEROS, 2008, p. 183-193) e, dentro dos setores, criar comunidades de família, animadas e coordenadas por equipes de leigos (DAp 372). Trata-se do modelo normativo da Igreja primitiva e antiga, a domus ecclesiae, que o Vaticano II resgata na eclesiologia Povo de Deus, em sua volta às fontes bíblicas e patrísticas. É a Igreja concebida como "eclesiogênese", continuamente se originando na proliferação da comunhão de pequenas comunidades (CODINA, 2008, p. 138145). Nos dados da pesquisa, como vimos, não se tem muito presente a distância entre a eclesiologia subjacente às CEBs e a eclesiologia presente nos movimentos apostólicos.

Um segundo pilar da tradição libertadora, que caracteriza o modelo de pastoral dos “padres das décadas de 1970/80", são as comunidades eclesiais como os sujeitos da evangelização. O Vaticano II, ao afirmar a base laical da Igreja, fundada no tríplice múnus da Palavra, da Liturgia e da Caridade, faz da comunidade dos fiéis como um todo o sujeito eclesial, resgatando o sensus fidelium. Com isso, dá-se a passagem do binômio clero-leigos para o binômio comunidade-ministérios (LG 31). Para Medellín, com o Vaticano II, se a comunidade dos batizados, em todos os seus membros, é o sujeito eclesial, então, é também a comunidade como um todo o sujeito da ação evangelizadora (Med 6,13; 9,6). Por isso, é preciso passar da paróquia tradicional, uma estrutura centralizadora e clerical, a comunidades de serviço no seio da sociedade, de forma propositiva e transformadora (Med 7,13). Para a Conferência de Santo Domingo, os leigos devem ser os protagonistas da evangelização, o que implica a promoção do laicato, livre de todo clericalismo e sem redução de sua atuação ao âmbito intra-eclesial (SD 97). Para Aparecida, a Igreja como um todo precisa estar em estado permanente de missão, de modo que "cada comunidade seja um poderoso centro irradiador da vida em Cristo". Comunidades evangelizadoras para uma Igreja missionária (DAp 362). Na pesquisa, ao se equiparar os movimentos apostólicos com as CEBs, se está contrapondo duas eclesiologias: uma préconciliar, que faz dos movimentos a extensão do braço do clero e, outra, a do Vaticano II, que faz da comunidade como um todo o sujeito da evangelização. 
Um terceiro pilar da tradição libertadora, que caracteriza o modelo de pastoral dos "padres das décadas de 1970/80", é uma Igreja que assume o pobre como sujeito e também seu lugar social, a periferia (BOFF, 1986, p. 27). O Vaticano II conclamou a Igreja inserir-se no mundo, pois, embora ela não seja deste mundo, está no mundo e existe para a salvação do mundo (LG 48). Medellín, entretanto, se perguntará: inserir-se no mundo, mas dentro de que mundo? Do mundo dos $20 \%$ dos incluídos ou do mundo dos $80 \%$ de excluídos? (GUTIÉRREZ, 2008, p. 126-139). É impossível evangelizar sem dar testemunho, sem estar com os pobres, sem solidarizar-se com sua situação, fazendo-se um com eles (Med 14,7). Para Puebla, a Igreja, conhecedora da situação de pobreza, marginalidade e injustiça da grande maioria da população, bem como de violação dos direitos humanos, deve ser cada vez mais a voz dos pobres, mesmo com o risco que isso implica (DP 1094). Para Santo Domingo, descobrir no rosto sofredor dos pobres o rosto do Senhor, é algo que desafia a todos os cristãos a uma profunda conversão pessoal e eclesial (SD 178). Aparecida ratifica e potencializa a opção pelos pobres, apoiando-se no Discurso Inaugural de Bento XVI: "a opção pelos pobres radica na fé cristológica” (DAp 392) (GUTIÉRREZ, 2008, p. 127-128). A Igreja na América Latina precisa continuar sendo, com maior afinco, companheira de caminho de nossos irmãos mais pobres, inclusive até o martírio (DAp 396). Ela está convocada a ser "advogada da justiça e defensora dos pobres", diante das intoleráveis desigualdades, que clamam aos céus (DAp 395). Opção pelos pobres não é assistencialismo e nem deixar de tomar posição diante da exclusão que tem causas estruturais. Os dados da pesquisa atestam como se tem tomado distância do mundo dos pobres e como tem minguado o serviço da Igreja no meio deles.

Um quarto pilar da tradição libertadora, que caracteriza o modelo de pastoral dos "padres das décadas de 1970/80", é uma evangelização libertadora. O Vaticano II superando o dualismo matéria-espírito, sagradoprofano, história e meta-história, concebe a salvação como redenção da pessoa inteira e de todas as pessoas (GS 45). Em consequência, para Medellín, como não há duas histórias, mas uma única história de salvação que se dá na história profana, a obra da salvação implica uma ação de libertação integral e de promoção humana a partir da intra-história (Med 2,14,a; 7,9; 7,13; 8,4; 8,6; 
11,5). Na evangelização, é preciso estabelecer laços entre evangelização e promoção humana $($ Med 7,9). Toda libertação é já uma antecipação da plena redenção em Cristo (Med 4,9). Consequente com o Vaticano II que afirma a vontade de Deus de salvar em comunidade, a promoção humana implica o estabelecimento de estruturas justas, condição para uma sociedade justa. Assim, a salvação se faz libertação - "toda libertação é já uma antecipação da plena redenção em Cristo" (Med 4,9). "Não teremos Continente novo, sem novas e renovadas estruturas" (Med 1,3), sem "o desenvolvimento integral de nossos povos" (Med 1,5). Santo Domingo, retomando Medellín, diz que a promoção humana significa passar de condições menos humanas a condições cada vez mais humanas (SD 162). Para Aparecida, a promoção da vida plena em Cristo, na perspectiva do Reino, nos leva a assumir as tarefas prioritárias que contribuem com a dignificação não só dos cristãos, mas de todos os seres humanos. Necessidades urgentes nos levam a colaborar, consequentemente, com outras pessoas, organismos ou instituições, para organizar estruturas mais justas, no âmbito nacional e internacional (DAp 384). Como denuncia Aparecida e os dados da pesquisa atestam, em lugar de uma evangelização integral, em determinados espaços da Igreja há a volta de espiritualidades pré-conciliares, desencarnadas e espiritualistas.

Um quinto pilar da tradição libertadora, que caracteriza o modelo de pastoral dos "padres das décadas de 1970/80", sãos os mártires das causas sociais. Para o Vaticano II, a Igreja precisa exercer uma diakonía histórica, ou seja, um serviço no mundo (GS 42), que contribua para o progresso e o desenvolvimento humano e social (GS 43). Por sua vez, Medellín, em sua opção pelos pobres e seu lugar social, faz da diakonía um serviço profético. Afirma que a missão evangelizadora se concretizará na denúncia da injustiça e da opressão, constituindo-se em um sinal de contradição para os opressores (Med 14,10). Lembra e encoraja que o serviço profético pode levar ao martírio, expressão da fidelidade à opção pelos pobres. Para Aparecida, o empenho da Igreja no continente em favor dos pobres redundou em perseguição e morte de muitos, que consideramos testemunhas da fé, nossos santos e santas, ainda não canonizados (DAp 98). Neste particular, constata que, em nossa experiência eclesial, as CEBs têm sido verdadeiras escolas de formação de cristãos comprometidos com sua fé, testemunhas de 
entrega generosa, até mesmo com o derramar do sangue de muitos de seus membros (DAp 178). Em nome da fé, deram a vida para que outros tivessem vida; foram consequentes com exigências históricas da mensagem evangélica. Trata-se de um testemunho que, sobretudo a perspectiva "institucional/carismática", tem dificuldade de reconhecer, com a tendência de ver os mártires das causas sociais, mais politizadores da fé do que inaugurando um novo perfil de santidade, já reconhecido pelo Papa Francisco na canonização de Dom Romero.

Como os dados da pesquisa atestam, estes e outros pilares do modelo de pastoral dos "padres das décadas de 1970/80", estão longe de se constituírem em suporte para a prática pastoral da perspectiva "institucional/carismática", particularmente dos "padres novos" a ela alinhados. E o mais preocupante é que tenha perdido terreno na ação pastoral dos próprios "padres das décadas de 1970/80". Continuam presentes, mas não mais com a mesma intensidade e entusiasmo. Não só mostram cansaço, como também distanciamento, mesmo sem regredir a modelos pré-conciliares. Como já são um contingente em menor número e este modelo de Igreja por décadas se afirmava ultrapassado, acabam acolhendo e convivendo com práticas impulsionadas ou fortalecidas pelos "padres novos", particularmente quando chegam a uma paróquia que os tiveram como predecessores.

\section{Possíveis razões do processo de involução eclesial ainda vigente}

Como explicar o distanciamento da renovação do Vaticano e da tradição eclesial libertadora, que os dados da pesquisa registram? De fato, nas últimas décadas, não só houve estancamento no processo de renovação do Vaticano II, como retrocesso em muitos campos (HUENERMANN, 2012, p. 284). O longo inverno eclesial (GONZÁLEZ FAUS, 1989, p. 67-84) que se estendeu até à renúncia do Papa Bento XVI, que por mais que se queira espiritualizá-la ou atribuíla à idade avançada no pontífice, não deixa de ser expressão do esgotamento de um projeto de "reforma da reforma" do Vaticano II. A Conferência de Aparecida, já havia constatado e denunciado o retrocesso: “[... ] tem nos faltado coragem, persistência e docilidade à graça 
para levar adiante a renovação iniciada pelo Concílio Vaticano II e impulsionada pelas anteriores Conferências Gerais, para assegurar o rosto latino-americano e caribenho de nossa Igreja" (DAp 10oh). Prova disso, diz o Documento, são “[...] algumas tentativas de voltar a uma eclesiologia e espiritualidade anteriores à renovação do Vaticano II" (DAp 10ob), acompanhadas da volta do clericalismo. Durante este período, sorrateiramente, em muitos aspectos se retrocedeu a práticas de neocristandade e a uma postura apologética frente ao mundo, típica de uma Igreja autorreferencial, que o pontificado de Francisco busca superar com o resgate da renovação conciliar.

Durante estas três décadas, em base a este modelo, mudou-se o perfil de bispo e também de presbítero, depois de uma visita de inspeção por parte da Cúria romana aos seminários, ainda na década de 1980. A partir de critérios passados às Nunciaturas apostólicas, implementou-se a eleição de um episcopado mais administrador que pastor, mais qualificado no direito canônico que em teologia. Da visita aos seminários, as novas orientações na formação levaram à ordenação de candidatos ao presbiterato mais identificados com o zelo da doutrina e a defesa da instituição eclesial, do que com uma evangelização integral no seio da sociedade moderna, autônoma e pluralista. Trata-se de um modo de ser Igreja, que se apoia sobre movimentos e associações apostólicas, de onde provém grande parte dos candidatos ao episcopado e ao presbiterato, pautados por uma missão centrípeta — sair para fora da Igreja para reconduzir as "ovelhas desgarradas" para o seio dela. O Papa Francisco está intervindo diretamente na mudança deste perfil, querendo bispos com "cheiro de ovelhas" e sem "psicologia de príncipes" e padres do meio do povo, inseridos nas periferias. Os resultados são minguados até agora, tanto que o processo de involução eclesial em relação à renovação do Vaticano II persiste e, em muitos lugares, de forma explícita, como no caso dos limites postos para a celebração da missa no rito tridentino. 


\section{Um projeto civilizacional em crise}

Para entender as razões da involução da Igreja em relação à renovação conciliar, a hipótese mais plausível é o impacto da crise do projeto civilizacional moderno. Na medida em que o Vaticano II significou a reconciliação da Igreja com o mundo moderno, a crise da modernidade afeta também diretamente o legado da renovação conciliar.

Sobram evidências de que estamos imersos em um tempo marcado por profundas transformações, que atingem todas as esferas da vida social, mergulhando-nos em um tempo de crise. Está aí a crise de paradigmas e das utopias, a crise das ciências e da razão, dos metarrelatos e das instituiçõos, crise de identidade, das religiões, de valores, crise de sentido, etc. Por um lado, a modernidade propiciou as maiores conquistas da humanidade, mas, por outro, também é a responsável pelas maiores frustrações da história. Não há como não reconhecer valores seus, como democracia, liberdade, igualdade, ciência, estado de direito, tecnologia, autonomia da subjetividade, tolerância, etc. Entretanto, além de serem conquistas que não chegaram a todos, deixando a margem multidões de descartados, a modernidade se caracteriza pela razão técnica-instrumental, em que na medida que reduziu tudo ao útil e aplicável, gerou um modo de vida e um modelo de economia, que coisifica o ser humano e depreda a natureza. E mais, a sociedade moderna fundada no mito do progresso deixou sem respostas as questões mais ligadas à finalidade do progresso e da aventura tecnológica, à realização humana e à felicidade pessoal, enfim, ao sentido da vida (VATTIMO, 1998, p. 640-646). Prova disso, é a irrupção de novas realidades, frente às quais o projeto civilizacional moderno tornou-se curto e, com elas, a emergência de novas aspirações e valores.

A crise da modernidade se impôs ainda na década de 1970 e tornou-se irrefutável com a queda do Muro de Berlin, em 1989. Praticamente, "tudo o que é sólido se desmancha no ar" (J. Beaudrillard), mergulhando-nos em uma sociedade líquida (BAUMAN, 2001) BENEDETTI, 2005, p. 17-18). É um tempo incômodo, pois, está permeado de incertezas e angústias, mais ingente à criatividade do que ao plágio ou para agarrar-se a velhas seguranças de um passado sem retorno. Gera reações diversas: negativamente a crise gera 
medo (que exagera o perigo e cria monstros); perplexidade (fica-se sem entender o que se passa e qual a saída); insegurança (sem saber que caminho escolher); angústia (pessoas desesperançadas, depressivas, agressivas)... E, positivamente, a crise desafia um novo nascimento (crise acrisola); impõe a urgência de se arriscar (coragem); desperta a criatividade (lançar-se a criar o novo); desafia a sonhar (com um mundo crescentemente melhor)... Como nos adverte a sabedoria oriental, crise não é "fim-da-história" ou "beco-semsaída”. Crise é encruzilhada, ocasião de novas oportunidades, mas à condição de não fugirmos dela. Crise é metamorfose, passagem, travessia, só que tanto para a morte como para um novo nascimento, dependendo de como a enfrentamos. Fugir dela, é presságio de um fim catastrófico; assumi-la, é prenúncio de um tempo pascal, de um novo começo (BRIGHENTI, 2004, p. 45-65).

\section{Uma crise que impacta a Igreja}

Também a instituição eclesial está mergulhada num tempo de crise. E nem poderia ser diferente, pois o mundo é constitutivo da Igreja. Não é o mundo que está na Igreja, mas é a Igreja que está no mundo. O Povo de Deus peregrina no seio de uma humanidade toda ela peregrinante. E o destino do Povo de Deus não é diferente do destino de toda a humanidade. E tal como na sociedade atual em relação à modernidade, também na Igreja há dificuldade em situar-se no novo tempo, para interagir com ele e, sobretudo, há dificuldade em aprender e enriquecer-se com as novas realidades emergentes. E tal como no âmbito da sociedade, no seio da qual as diferentes hermenêuticas da crise da modernidade se configuram em projetos sociais distintos, no âmbito eclesial, as diversas hermenêuticas do Vaticano II e da tradição latino-americana, também configuram modelos de pastoral diferentes e, em muitos aspectos, antagônicos (FLORISTÁN, 1984, p. 417426).

Concretamente, frente à crise atual que gera insegurança, aqueles que se deixam levar pelo medo, instintivamente, vão buscar segurança. E segurança em tempos de travessia e do imperativo de criar o novo, somente falsas seguranças, que são basicamente duas: o tradicionalismo e o emocionalismo. No contexto atual, os que reagem à crise atual com uma 
visão retrospectiva da realidade, fazendo do passado um refúgio, se agarram à pastoral de conservação, o modelo de pastoral da cristandade medieval, devocional e sacramentalista. Ou então resgatam a pastoral coletiva, o modelo de pastoral da neocristandade, em postura apologética frente ao mundo moderno, defendendo a "tradição' e a "doutrina de sempre". O refluxo destes modelos se dá através dos movimentos e associações alinhados à Igreja pré-conciliar, postura assumida pelo clero mais jovem, em sua grande maioria (BRIGHENTI, 2015, p. 23-34). O Concílio Vaticano II superou estes dois modelos, através do modelo caracterizado anteriormente e objeto de análise das questões em foco aqui.

A pastoral de conservação, assim denominada por Medellín (Med 6,1) e nomeada por Aparecida (DAp 370), é o modelo de pastoral do regime de cristandade (FLORISTÁN, 1991, p. 269-270), que funciona centralizado no padre e na paróquia e, no seio desta, na matriz. Na pastoral de conservação, em sua configuração pré-tridentina, a prática da fé é de cunho devocional, centrada no culto aos santos e composta de procissões, romarias, milagres e promessas, práticas típicas do catolicismo popular medieval; e em sua configuração tridentina, a vivência cristã gira em torno do padre, baseada na recepção dos sacramentos e na observância dos mandamentos da Igreja. Já a pastoral coletiva é o modelo de pastoral do regime de neocristandade (BRIGHENTI, 2012, p. 123-124), que teve seu auge no século XIX, quando a Igreja pré-moderna jogou suas últimas cartas no confronto com a modernidade (cf. QUEIRUGA, 2000). Nela assume a defesa da instituição católica diante de uma sociedade anti-clerical e a guarda das verdades da fé frente uma razão secularizante. Ao desconstrucionismo dos metarrelatos e do relativismo reinante que geram vazio, incertezas e medo, contrapõe-se o "porto de certezas" da tradição religiosa e um elenco de verdades apoiadas numa racionalidade metafísica. Neste modelo de Igreja e de pastoral, em lugar do Vaticano II (MELLONI, 2005, 34-59), que teria se rendido à modernidade, apregoa-se a "volta ao fundamento", guardado zelosamente pela tradição anti-moderna, que acertadamente excomungaram em bloco a modernidade (GONZÁLEZ FAUS, 1989, p. 67-84). A redogmatização da religião e o entrincheiramento identitário acabam sendo sua marca, apoiados na 
racionalidade pré-moderna. E onde anda a pastoral do Vaticano II e da tradição libertadora?

Será que existem na Igreja também aqueles que, em meio à crise, olham para frente, com uma visão prospectiva? Sim, aqueles que fizeram do Vaticano II, mais do que um ponto de chegada, um ponto de partida, como frisou Paulo VI em seu encerramento. Estes, já foram maioria, mas hoje são quase minoria. Em muitos lugares, são brasas sob cinzas. Ultimamente, entretanto, com a arejada de Aparecida e do pontificado do Papa Francisco ao resgatarem o Vaticano II e a tradição eclesial libertadora, as chamas voltaram a arder, ainda que tímidas em meio a tantas adversidades.

É a Igreja das pequenas comunidades inseridas profeticamente na sociedade, para além do paroquialismo e do universalismo dos movimentos supra-diocesanos (LIÉGÉ, 1978, p. 243-256); é a Igreja da opção pelos pobres, que faz deles sujeitos de uma sociedade inclusiva e não meros objetos de caridade; é a Igreja da Campanha da Fraternidade e das pastorais sociais, alimentada na mística dos mártires e em uma espiritualidade libertadora; é a Igreja sinodal da pastoral orgânica e de conjunto em processos de planejamento participativo e dos conselhos e assembleias de pastoral; é a superação de uma Igreja auto-referencial, em relação ecumênica e interreligiosa; enfim, é a Igreja que busca ser toda ela ministerial, para além do binômio clero-leigos, etc.

Mas, esta é também uma Igreja perplexa. E não só porque precisa mudar a linguagem. As intuições básicas e eixos fundamentais do Vaticano II e da tradição libertadora continuam válidos, mas o contexto mudou e nos deparamos todos com novos desafios e a irrupção de novos valores. Como conjugar - comunidade e autonomia (há uma crise de compromisso comunitário, também por conta de comunitarismos); militância e gratuidade (o outro como alteridade gratuita e não simplesmente como imperativo ético); utopia e vida presente (a insustentabilidade de uma utopia concebida como dilatação indeterminada do futuro); objetividade e subjetividade (a veracidade e a legitimidade de diferentes versões do mesmo); global e local (não perder de vista o real da realidade diante de um globalismo que volatiza o real); autoridade e consenso (a verdade como consenso das diferenças no ato comunicativo dos diferentes); etc. 


\section{Concluindo}

O modelo pastoral dos "padres das décadas de 1970/80", que aqui esteve em análise, se remete à renovação conciliar, recebida criativamente pela Igreja na América Latina, que redundou na tradição eclesial libertadora, tecida em torno a Medellín. Não se trata, entretanto, de algo propriamente novo. É consequência e desdobramento das intuições básicas e eixos fundamentais do Concílio Vaticano II, em nosso próprio contexto. É neste meio que os "padres das décadas de 1970/80" nasceram, se formaram e exercem seu ministério, hoje, com outras características. Já os "padres novos" nasceram e foram formados no contexto da "involução eclesial" nas décadas que antecederam o atual pontificado e, hoje, exercem seu ministério, desconcertados por um pontificado que resgata justamente o que Ihes parecia página virada de um passado sem retorno. Depois de três décadas de "involução eclesial", durante as quais a tradição libertadora sofreu toda sorte de tribulações e mesmo punições, com Aparecida abriu-se um novo cenário eclesial, fortalecido com o pontificado do Papa Francisco, que tem reafirmado a renovação do Vaticano II na perspectiva de sua "recepção criativa" feita pela Igreja na América Latina.

Os dados globais da pesquisa, assim como atestam também os resultados da consulta aos agentes eclesiais em relação às questões aqui em foco, apontam para a vigência de duas perspectivas teológico-pastorais. Uma delas está alinhada à renovação do Vaticano II e à tradição libertadora da Igreja na América Latina, à qual se integram os "padres das décadas de 1970/80", que convencionamos denominá-la "perspectiva evangelização/libertação". A outra é integrada por segmentos da Igreja que tomam distância da renovação conciliar e da tradição libertadora, à qual se alinham os "padres novos" e que denominamos "perspectiva institucional/carismática". Os dados aqui analisados confirmam a hipótese de se tomar o Vaticano II como um divisor-de-águas na vida da Igreja e como uma chave hermenêutica obrigatória para abordar a situação da Igreja hoje, em particular para caracterizar o perfil dos "padres novos". Como pano-defundo da configuração das duas perspectivas, tal como já nos referimos, está a crise do projeto civilizacional moderno e, junto dela, também a crise do 
Vaticano II, como o qual a Igreja se reconciliou no Concílio. Sem que suas intuições básicas e os eixos fundamentais tenham caducado, no entanto, a crise atual obriga os "padres das décadas de 1970/80", a resituar a renovação conciliar e a tradição latino-americana no atual contexto e a fazer nele uma segunda recepção. É assim que contribuirão, juntamente com todos os que guardam e vivem seu legado, para que os "padres novos" e os demais segmentos alinhados à perspectiva "institucional carismática" e outros, descubram e encarnem no novo contexto em que vivemos, a preciosa herança do Vaticano II, um kairós para a Igreja nos umbrais do terceiro milênio.

\section{Referências}

AZEVEDO, M. Comunidades eclesiais de base e inculturação da fé. São Paulo: Loyola, 1986.

BAUMAN, Zygmunt. Modernidade Líquida. São Paulo : Zahar, 2001.

BENEDETTI, L. R. "Quando un tissu social se déchire». In: MULLER, H. A. ; VILLEPELET, M. D. Risquer la foi dans nos sociétés. Églises d'Amérique latine et d'Europe en dialogue. Paris: Karthala, 2005. p. 12-29.

BOFF, L. Teología desde el lugar del pobre. Santander: Sal Terrae, 1986.

BRIGHENTI, A. A Igreja Perplexa. A novas perguntas, novas respostas. São Paulo: Paulinas, 2004.

BRIGHENTI, A. "A pastoral na vida da Igreja. Repensando a missão evangelizadora em tempos de mudança". In: CNBB-Comissão episcopal para a Animação Bíblicocatequética. Brasília: Ed. CNBB, 2012. p. 123-124.

BRIGHENTI, A. A ação pastoral em tempos de mudança: modelos obsoletos e balizas de um novo paradigma. Vida Pastoral, São Paulo, p. 23-34, 2015.

CODINA, V. "A eclesiologia de Aparecida”. In: AMERINDIA. V Conferência de Aparecida. Renascer de uma esperança. São Paulo: Paulinas, 2008. p. 138-145.

DUSSEL, E. De Medellín a Puebla. Uma década de sangue e esperança I. De Medellín a Sucre, 1968-1972. São Paulo: Paulinas: 1981.

FLORISTÁN, C. Modelos de Iglesia subyacentes a la acción pastoral. Concilium 196, p. 417-426, 1984.

FLORISTÁN, C. Teología Práctica. Teoría y práxis de la acción pastoral. Salamanca: Ed. Sígueme, 1991. 
GONZÁLEZ FAUS, J. I. El meollo de la involución eclesial. Razón y Fe 220, n. 1089/90, p. $67-84,1989$.

GUTIÉRREZ, G. "La recepción del Vaticano II en América Latina”. In: FLORISTÁN, C.; TAMAYO, J. J. (eds.). El Vaticano II, veinte años después. Madrid: Cristiandad, 1985. p. 213-237.

GUTIÉRREZ, G. “Aparecida: La opción preferencial por el pobre”. In: AMERINDIA. V Conferência de Aparecida. Renascer de uma esperança. São Paulo: Paulinas, 2008. p. 126-139.

HOUTART, F. "Le Conseil Épiscopal d'Amérique latine accentue son changement". ICI, Paris, n. 481, p. 10-24, 1975.

HUENERMANN, P. Silêncio frente ao Concílio Vaticano II? Concilium 346, n. 3, p. 283296, 2012.

LIÉGÉ, P. A. Comunidad y comunidades en la Iglesia. Madrid: Herder, 1978.

LIMA VAZ, H. C. Igreja-reflexo vs Igreja-fonte. Cadernos Brasileiros, n. 46, p. 17-22, 1968.

MELLONI, A. O que foi o Vaticano II? Breve guia para os juízos sobre o Concílio. Concilium 312, n. 4, p. 34-59, 2005.

OLIVEROS, R. "Igreja particular, paróquia e CEBs em Aparecida”. In: AMERINDIA. V Conferência de Aparecida. Renascer de uma esperança. São Paulo: Paulinas, 2008. p. 183-193.

QUEIRUGA, A. T. Fin del cristianismo premoderno. Santander: Sal Terrae, 2000.

SOBRINO, J. "El Vaticano II y la Iglesia latinoamericana". In: FLORISTÁN, C.; C.TAMAYO J. J. (eds.). El Vaticano II, veinte años después. Madrid: Cristiandad, 1985. p. 105-134;

VATTIMO, G. “Posmodernidad”. In: ORTIZ-OSÉS, A.; LANCEROS, P. Diccionario de Hermenéutica. Bilbao: Universidad de Deusto, 1998. p. 640-646. 